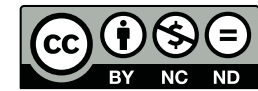

Estudos Teológicos foi licenciado com uma Licença Creative Commons Atribuição - NãoComercial - SemDerivados 3.0 Não Adaptada

http://dx.doi.org/10.22351/et.v58i1.2990

\title{
De mãe de Jesus à Senhora do Céu: A EVOLUÇão da deVoÇão À VIRGEM MARIA NA IGREJA CRISTÃ MEDIEVAL ${ }^{1}$
}

\author{
From Mother of Jesus to the Lady of Heaven: \\ the evolution of devotion to the Virgin Mary in the medieval Christian Church
}

Rodrigo Portella ${ }^{2}$

Resumo: A Igreja Católica celebrou, em 2017, no Brasil e em Portugal, o chamado Ano Mariano, em referência aos 300 anos de descoberta da imagem de Aparecida e dos 100 anos das manifestações marianas em Fátima. Embora sejam bastante presentes entre nós - particularmente aos católicos - aspectos dessas duas devoções modernas, ainda são incipientes, no Brasil, análises sobre a devoção mariana no período medieval. No âmbito do Ano Mariano, o presente artigo pretende oferecer uma visão histórica sobre o desenvolvimento da devoção e iconologia mariana durante a Idade Média. Portanto o artigo analisa as representações e imaginários de Maria a partir de contextos sociais e eclesiásticos de cada época do período medieval, destacando como Maria passa de figura imperial e ligada ao poder civil e eclesiástico a formas figurativas e devocionais mais ligadas, especificamente, à vida e às preocupações diárias do povo.

Palavras-chave: Maria. Idade Média. Devoção. Iconologia.

Abstract: The Catholic Church celebrated in 2017, in Brazil and Portugal, the so-called Marian Year, in reference to the 300 years of discovery of the image of Aparecida, and the 100 years of the Marian manifestations in Fatima. Although they are quite present among us - particularly Catholics - aspects of these two modern devotions, an analysis of Marian devotion in the medieval period is still incipient in Brazil. Therefore, in the context of the Marian Year, this article intends to offer a holistic view on the development of Marian devotion and iconology during the Middle Ages. Therefore, it analyzes the representations and imaginary of Mary from the social and ecclesiastical

1 O artigo foi recebido em 30 de março de 2017 e aprovado em 13 de junho de 2017 com base nas avaliações dos pareceristas ad hoc.

2 Doutor em Ciência da Religião pela Universidade Federal de Juiz de Fora - UFJF, em Juiz de Fora/MG, com estágio de pós-doutoramento em Teologia pela Pontifícia Universidade Católica do Rio de Janeiro - PUC-RJ, no Rio de Janeiro/RJ, e em Sociologia pela Universidade do Minho, Portugal. Professor do Programa de Pós-Graduação em Ciência da Religião da UFJF. O presente artigo é uma versão adaptada e revista de parte do primeiro capítulo do livro "Mirar Maria: reflexos da Virgem em espelhos da História" (Aparecida: Santuário; Academia Marial, 2016). Contato: rodrigo@portella.com.br 
contexts of each period of the medieval period, highlighting how Mary passes from imperial figure and linked to the civil and ecclesiastical power to the figurative and devotional forms more specifically related to the daily lives and concerns of the people. Keywords: Mary. Middle Ages. Devotion. Iconology.

\section{Introdução}

A proeminência da figura de Maria, no cristianismo, surge já nos primeiros séculos da era cristã, mas desenvolve-se com mais robustez a partir da Idade Média. Como não é nosso interesse esboçar uma "síntese da história da mariologia" - ou algo que o valha -, não abordamos cronologias e pormenores em relação a como e por que Maria foi adquirindo papel cada vez mais importante na devoção e na teologia cristãs. Portanto, como ponto histórico aproximado de referência, para se achegar até alguns sentidos atribuídos a Maria, propomos o ano 800, data em que Carlos Magno foi coroado imperador pelo papa Leão III, o que fez surgir o Sacro Império Romano-Germânico. ${ }^{3}$ Evidente que, muito antes de tal data, Maria já era venerada entre os cristãos, e a devoção - e teologia - mariana já havia se desenvolvido. Portanto, também, de forma breve, vamos nos referir a imagens e conceitos marianos anteriores ao ano 800. Fica claro, então, que o ano 800 serve tão somente de parâmetro simbólico. Ou seja, as ideias, devoções e manifestações marianas - em sua miríade de formas - a constar neste artigo referem-se, principalmente, a momentos posteriores ao ano 800, tendo como data limite o século XVI, em que a Reforma protestante e a resposta a ela pelo Concílio de Trento criam novos ambientes eclesiais e teológicos, e, no âmbito católico, definem-se e redefinem-se, em Trento, questões salientes relacionadas à imagem e devoção à Maria.

\section{De mãe judia à majestade universal}

O que os cristãos do ano 800 herdaram dos seus antepassados em relação à imagem e devoção da Virgem? A partir de nossa interpretação estritamente sociológica (nesse ínterim específico), talvez possamos dizer que, após a religião cristã ter se tornado a religião oficial do Império Romano (século IV e adiante), Maria é, aos poucos, identificada como a mãe rainha, Senhora e nobre, pois mãe do Pantocrator, do Senhor potente, do imperador celeste. Neste contexto Maria surge como a mãe de Deus (Theotokos, como define, teologicamente, o Concílio de Éfeso), daquele que a

\footnotetext{
Opto por tal data, pois compreendo que, após o fim da Antiguidade e a reorganização da Europa no alvorecer da Idade Média, é a partir do Sacro Império Romano-Germânico que se inicia - guardadas as devidas proporções - a unidade cultural cristã de maior envergadura na história da cristandade, promovida pela reorganização política representada pelo nascente império secundado pela igreja cristã do Ocidente. Ademais, de forma mais ou menos arbitrária, essa data pode simbolizar a maior unicidade teológica e administrativa da igreja ocidental, após a realização dos principais concílios ecumênicos dogmáticos e, igualmente, após a superação da maior parte das heresias, particularmente a do arianismo.
} 
tudo governa. Como, na mentalidade corrente, os governos dos séculos cabiam aos reis e imperadores, aos nobres e bem-nascidos, naturalizou-se identificar Jesus como um soberano celeste, à maneira dos soberanos mundanos, e, por conseguinte, sua mãe como uma espécie de imperatriz. ${ }^{4}$

Claro que, no cristianismo primitivo, antes da chamada "virada constantiniana", Maria, na esteira do estamento social e político conferido aos cristãos, isto é, a marginalidade, surge de forma diversa, ou seja, a partir de uma concepção mais próxima à literalidade bíblica das narrativas da infância de Jesus, como se apresenta na figura 1.

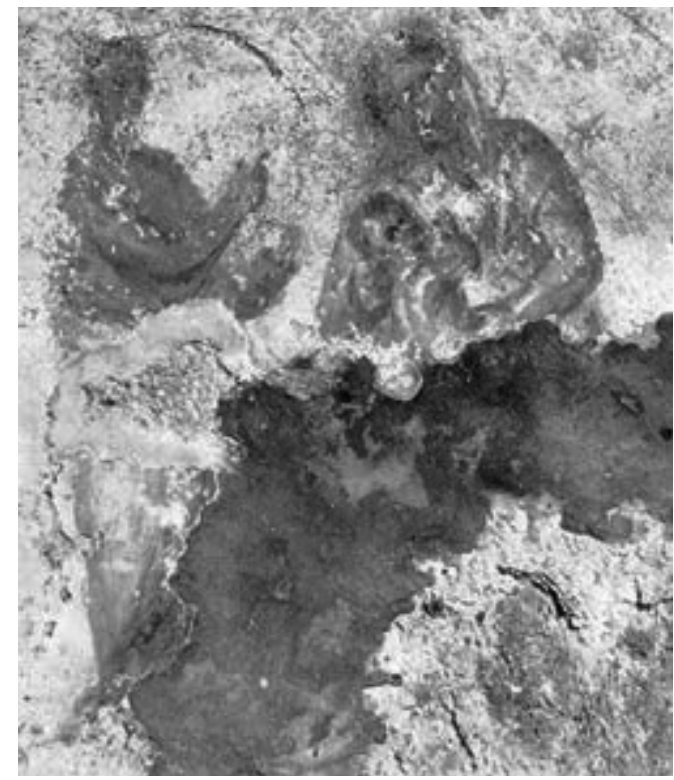

Figura 1. Catacumbas de Priscila (capela grega), Roma, Itália (século II d.C.).

Virgem, menino e o profeta Balaão

A referida pintura é uma das primeiras representações da Virgem, em que Maria está com Jesus entre os braços, e data, provavelmente, do século II. Segundo Amato $^{5}$, a pessoa ao lado da Virgem é o profeta Balaão, apontando o surgimento da estrela que anuncia Jesus. A figuração da Virgem, em seu culto primitivo, ainda era muito incipiente, rústica e clandestina (nas catacumbas), e fazia referência às cenas e personagens bíblicos. De qualquer forma é preciso frisar que, desde o início de suas

4 Caso se queira interpretar esse encontro entre a mulher e o poder a partir da psicologia analítica, pode-se partir da perspectiva junguiana em que Maria integra anima (feminilidade, maternidade, virgindade) e animus (reinado, cetro, governo, soberania) (GRÜN, Anselm; REITZ, Petra. Festas de Maria: um diálogo evangélico-católico. Aparecida: Santuário, 2009. p. 18).

5 AMATO, Pietro. Arte|Iconologia. In: DE FIORES, Stefano; MEO, Salvatore (Orgs.). Dicionário de Mariologia. São Paulo: Paulus, 1995. p. 151-163. p. 152. 
representações iconográficas, Maria surge sempre em função de Jesus, ou seja, para "contar" a história de Jesus, portanto ela surge assim como outros personagens bíblicos também ilustrados à época, sem aparente proeminência sobre eles.

Contudo, com o estabelecimento do cristianismo como religião oficial, Maria adquire, gradualmente, status diferente em relação aos demais personagens bíblicos. E na iconografia surgem, ao seu lado, personagens que não necessariamente tiveram ligação com as fontes bíblicas, mas que pertenciam ao poder político e religioso de então, como é possível observar na figura 2.

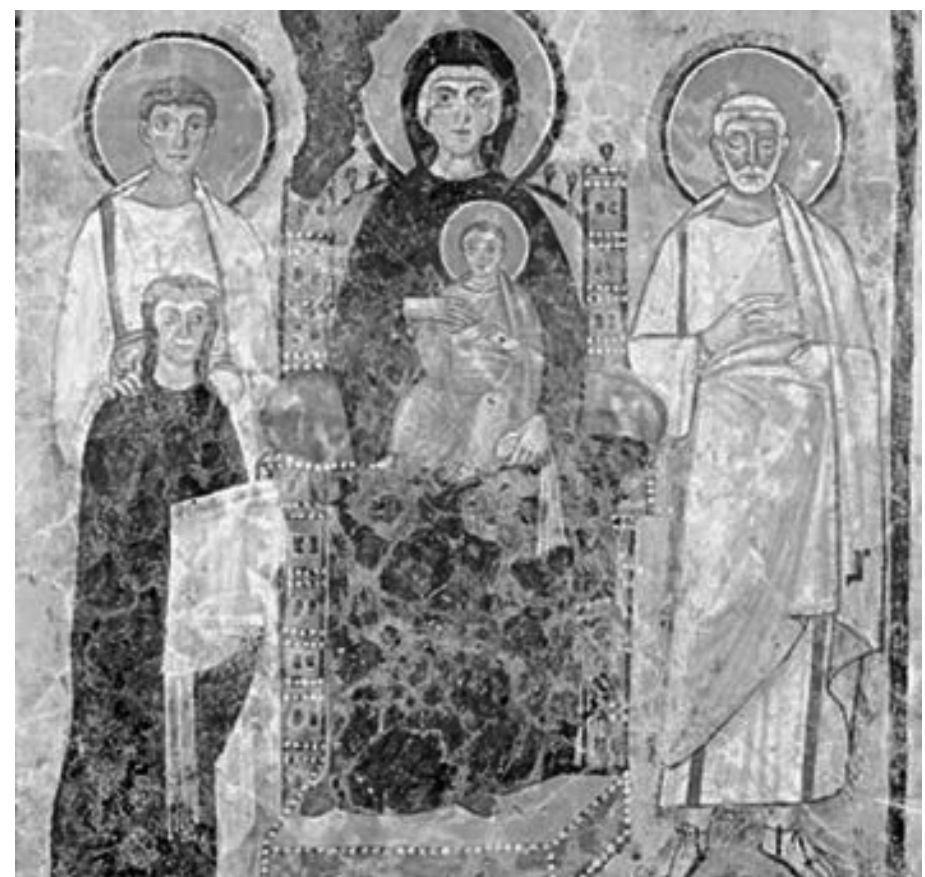

Figura 2. Catacumbas de Comodila, Roma, Itália (sec. VI d.C.)

Como se depreende da imagem, já no século VI, com a igreja livre e abençoada pelo poder secular, Maria surge como figura centralizada - embora, ainda, em função do centro maior, Jesus, sobre seu colo -, e não mais, necessariamente, na moldura de cenas bíblicas, mas no ornato de elementos figurativos que evocam, de forma mais hierática, o poder de uma matrona ladeada por seus auxiliares (os santos e mártires) e, também, dos mecenas que, em vida, se faziam retratar ao seu lado, como que se colocando sob seu patrocínio. Neste caso, a viúva Túrtura ${ }^{6}$ aparece em plano inferior e em figura menor, salientando ser menos do que os santos e do que a Virgem - que ocupa o plano central -, porém, manifestando a proximidade com a mãe de Deus e,

6 Nobre cartaginense do século VI, viúva de Severiano e mãe da abadessa Santa Florentina de Cartagena. 
assim, legitimando sua posição social. Portanto Maria passa a ser percebida, através da lente da arte, como aquela que, de certa forma, faz parte do status quo e o legitima. Isso, aliás, parece-me bastante natural para uma época em que a religião era subsumida pela política e vice-versa, ou seja, em que as fronteiras modernas entre o secular e o religioso ainda não estavam traçadas. Essa forma de entrelaçamento entre religião e política - e da figuração de Maria a partir de tal entendimento - prevalecerá durante muitos séculos, embora com os matizes culturais, teológicos e políticos específicos de cada época.

Destarte também é necessário destacar que a figura de Jesus no colo de sua mãe, embora possa, é claro, evocar uma forma de relacionamento comum entre mãe e filho, não leva, explícita e diretamente, a nenhuma figura narrativa da Bíblia a respeito da história de Jesus e de Maria (nem mesmo à história do nascimento de Jesus). Esse tipo de representação iconográfica teria um motivo mais teológico, ou seja, muitas das imagens da Virgem com Jesus no colo - ao menos nos primeiros séculos - remetem às lutas doutrinárias que defendiam a maternidade divina de Maria. ${ }^{7}$

Pouco depois do alvorecer da Idade Média, Maria, como Theotokos 8 , era, também, representada em pequenas estátuas talhadas de um só bloco de madeira, geralmente escuro, a figurá-la com o rosto impassível - ou um tanto afetuoso -, sentada no trono e mostrando, sentado ao seu joelho, o menino Jesus, figurado, como ela, de frente. São as "Virgens em majestade", como no exemplo da figura 3.

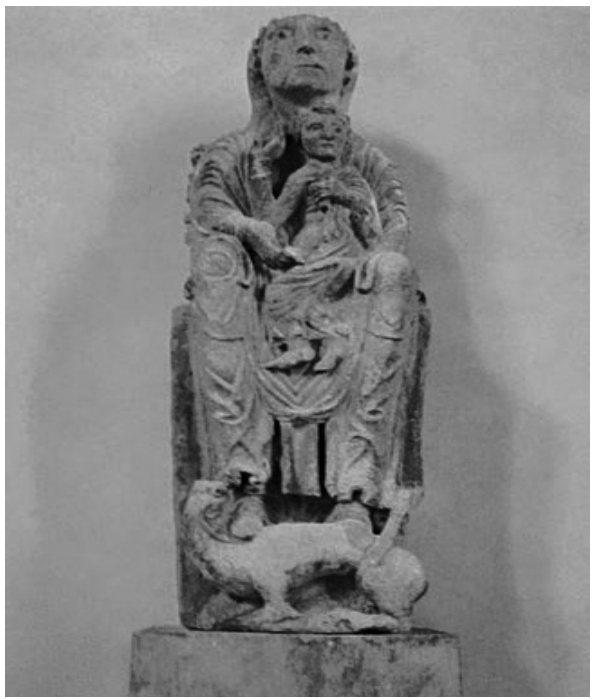

Figura 3. Virgem em majestade (Sedes Sapientiae). Santa Maria im Kapitol, Colônia, Alemanha

7 AMATO, 1995, p. 157.

8 "Mãe de Deus", em grego. O Concílio de Éfeso deu tal definição para clarificar, dogmaticamente, que Maria deu à luz a Jesus por inteiro, na unidade de seu ser divino e humano, contra a opinião do patriarca de Constantinopla Nestório, que defendia que Maria teria gerado apenas a natureza humana de Jesus.

9 DUQUESNE, Jacques. Maria. Rio de Janeiro: Bertrand Brasil, 2005. p. 108. 
Ou seja, uma Virgem altiva, longe do povo, acima dele, reinando nos céus. Não é, ainda, a Virgem da misericórdia, a advogada nossa do medievo posterior. Ela não pede a Jesus pelo povo, mas reina com e como ele, não o olhando de frente para suplicar-lhe pelas almas desassossegadas.

Na figura 3 - produzida na altura central da época medieval -, Maria e Jesus são apresentados, ambos, entronizados em majestade, com vestimentas suntuosas. Maria usa coroa - ausente em Jesus que, por sua vez, ampara sua mãe - e aponta para seu filho, mostrando de quem provém sua realeza e a quem se deve, prioritariamente, dirigir o olhar. Ambos olham a partir da glória (abside) ao expectador, que os vê acima de si, nas alturas, como soberanos máximos. Jesus segura um códice onde está escrito veni, electa mea, et ponam in te thronum meum (vem, ó minha eleita, e compartilha de meu trono), frase retirada da liturgia da festa da Anunciação. Maria, por sua vez, traz um rolo com um versículo do Cântico dos Cânticos (2.6) em que se lê leva eius sub capite meo et dextera illius amplexabitur me (sua mão esquerda está sob a minha cabeça, e sua direita me abraça), legitimando, assim, por meio da Bíblia, sua posição majestática. Conforme Amato ${ }^{10}$,

a imagem da virgem rainha [...] em Santa Maria in Trastevere, em Roma, serve para ilustrar o Cântico dos cânticos [...]. A basílissa está sentada ao lado de Cristo, no mesmo trono. O livro aberto segurado por Cristo registra: "Veni electa mea et ponam in te thronum meum". O encontro do esposo com a esposa, comentam os escritores medievais, significa o encontro de Cristo com a Igreja.

E o mesmo autor arremata: "A coroa real, ornada com gemas, tornou-se quase uma norma para a Virgem com o menino durante a Idade Média"11. Maria, portanto, desde o início do medievo, encarna crescentemente a figura daquela que rege, com Jesus, os destinos dos reinos e de seus súditos, e a riqueza em sua representação passa a significar o direito que assiste a uma figura nobiliárquica de sua grandeza.

Contudo, como se depreende, Maria, sobretudo até os inícios do ano 1000, está constantemente representada em relação a Jesus, isto é, é aquela que apresenta Jesus em seus braços ou em seu colo. Nos ícones orientais, essa função mariana se torna mais clara, pois são abundantes as imagens em que Maria aponta para Jesus, como a apresentar seu filho, especificando ser ele o caminho, a figura para a qual o devoto deve dirigir seu olhar e atenção, como no ícone da figura 4.

\footnotetext{
${ }_{10}$ AMATO, 1995, p. 155.
}

${ }_{11}$ AMATO, 1995, p. 158. 


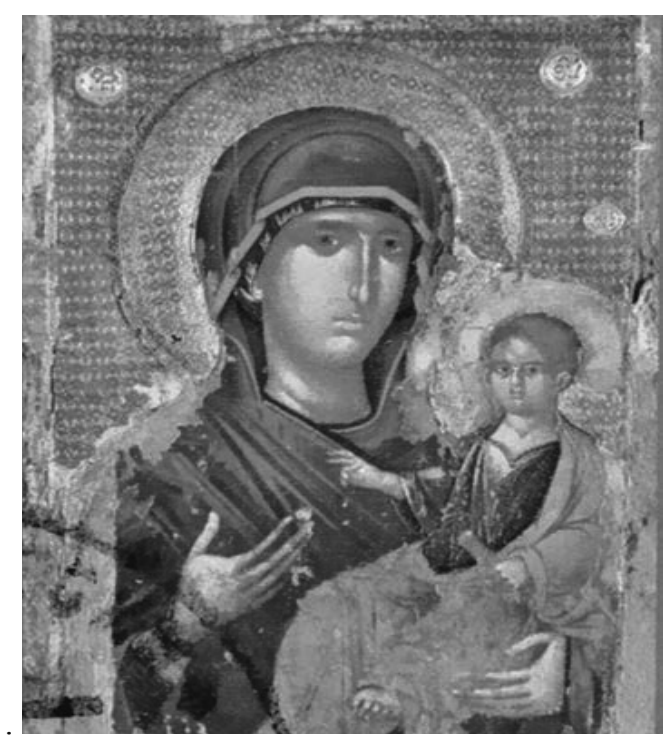

Figura 4. Ícone sérvio da Hodegetria, datado do século XIV. Museu Nacional da Sérvia

A Hodegetria - significando, em grego, "ela que mostra o caminho" - aponta para Jesus, o caminho, que a abençoa. É a Theotókos, usando o véu (marphórion), que olha para o devoto, a indicar-lhe o caminho Jesus. Jesus, embora menino, tem a fisionomia adulta e segura um rolo. Jesus é o centro, e a mãe surge em função do filho. ${ }^{12}$ Figuras como essa, particularmente no Oriente, estavam sob o interesse da defesa do dogma calcedoniano (451 d.C., em que foi declarado que Jesus é homem e Deus a um tempo, segunda pessoa da Trindade) e de Éfeso (431 d.C., que declarou ser Maria a Mãe de Deus). Neste sentido, a simbologia visual, particularmente dos ícones, supera os motivos puramente devocionais, expressando, outrossim, determinada catequese para a fé.

Se na primeira Idade Média Maria pode ser interpretada como a legitimadora da soberania imperial e pode ser identificada com a igreja (mãe de Deus = mãe da igreja), por volta do ano 850, Maria passa a ser, também, definida como mediadora entre o céu e a terra, e invocada de forma mais pessoal como mãe dos cristãos. ${ }^{13} \mathrm{~A}$ partir de tal sensibilidade religiosa, Maria passa a ser concebida como a coadjutora de Jesus, isto é, aquela que, estando junto ao seu filho, amealha, aos seus devotos, graças e milagres. Assim, os ícones também expressam ou representam o poder mariano, como na figura 5.

12 AMATO, 1995, p. 153.

13 BARNAY, Sylvie. Maria. In: VAUCHEZ, André. Cristianismo. Dicionário dos tempos, dos lugares e das figuras. Rio de Janeiro: Forense Universitária, 2013. p. 263-264. p. 263. 


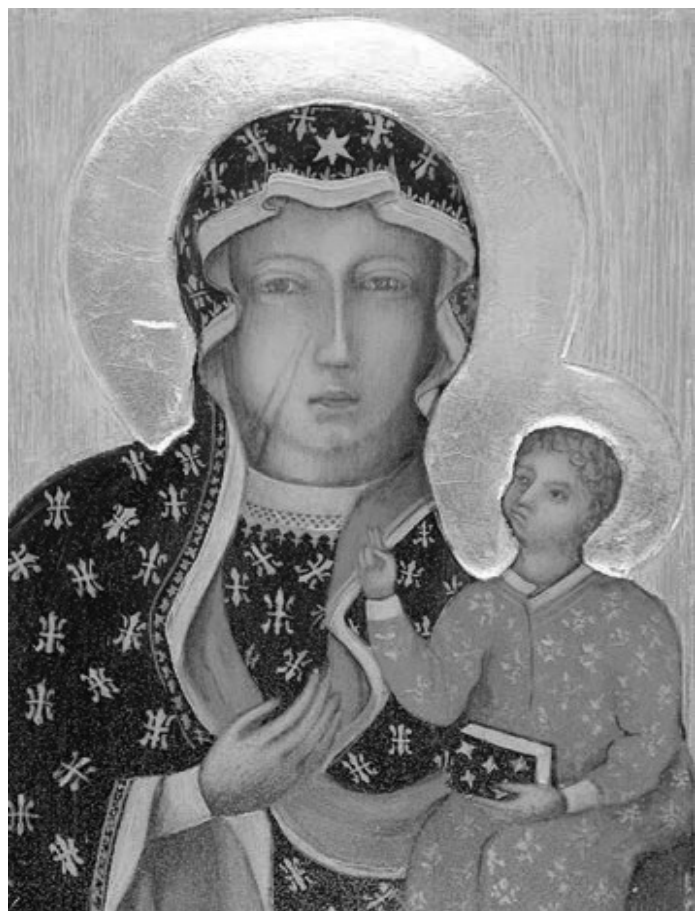

Figura 5. Ícone da Virgem de Czestochowa, séculos XII-XIII

Uma das famosas imagens de Maria a fazer milagres é a do ícone da Virgem de Czestochowa. Assim como se faz, atualmente, com a imagem da Virgem de Schoenstatt, esse ícone - que tem muitas cópias - era e é levado de casa em casa para veneração.

Contudo, a projeção mariana no cenário da devoção popular, embora de maturação paulatina, tende a ganhar força ímpar com as reformas monásticas do século XII. Se até o século XI eram as relíquias dos mártires e santos que impeliam o culto popular, a partir do século XII o culto a Maria, incentivado, sobretudo, pelos monges cistercienses e pelos frades mendicantes, ganha maior vulto e importância. ${ }^{14}$ Foi Bernardo de Claraval (1090-1153), pai do monaquismo cisterciense renovado, quem criou um "novo estilo" de mística e veneração em relação à Virgem Maria ${ }^{15}$, de cariz mais afetivo e humano, representado por orações, poesias e inflamados sermões dedicados à Virgem. ${ }^{16}$ Por exemplo, sabe-se que as quatro festas marianas da igreja antiga,

${ }^{14}$ BEIRANTE, Maria Ângela. Territórios do Sagrado. Crenças e comportamentos na Idade Média em Portugal. Lisboa: Colibri, 2011. p. 80.

${ }^{15}$ LENZENWEGER, Josef. História da Igreja Católica. São Paulo: Loyola, 2006. p. 169.

16 Talvez seja melhor dizer que Bernardo de Claraval, Doutor Melífluo, deu estrutura mais formal - principalmente através da cultura letrada - a um aspecto da devoção mariana que foi despontando aos poucos e que achou em sua época terreno fértil para maior sistematização. 
anteriores ou concomitantes ao início da alta Idade Média, eram: Nascimento, Anunciação, Purificação, Falecimento ${ }^{17}$, isto é, todas ligadas à vida de Maria na Palestina, sendo que duas delas (Nascimento e Falecimento) não são relatadas no cânon bíblico, mas "fatos" conhecidos por meio dos escritos apócrifos. Enfim, Maria era venerada em estreita ligação à sua história e ao testemunho bíblico. Com o advento dos séculos XI e XII, e adiante, a Virgem - em suas imagens e devoções - passa a ser referenciada para além da recordação bíblica ou dogmática de até então e ganha novos contornos em que se "encarna" de vez no dia a dia das pessoas, chegando mais próxima à vida do cotidiano e das afetividades.

Mas não foram apenas os mosteiros reformados e as ordens mendicantes que alçaram o culto mariano a uma concentração, da motivação do mesmo, na própria figura de Maria e em sua ligação com o cotidiano e a afetividade. Também a cultura cavalheiresca, na altura, foi marcante a determinar novas relações e visões societárias em relação à mulher e, no caso, à mulher protótipo e símbolo do feminino na religião cristã, Maria. Pode-se, portanto, destacar duas características marcantes do período zênite do medievo: a exaltação, em movimento ascendente, da figura de Maria per se, enquanto mulher símbolo da mulher perfeita; e, em movimento descendente, a aproximação de Maria à vida, dores, mazelas e esperanças do povo. Aparentemente contrários, ambos os movimentos convergem um ao outro.

\section{Tota pulchra es Maria}

No medievo, o ambiente do culto à dama e do amor cortês influenciou imensamente a relação das pessoas com a Virgem Maria. $\mathrm{O}$ amor cortês remete a

um novo ascetismo - o Amor não é feito para ser satisfeito e gasto, mas para gostar e condoer-se dele na eternidade. Há no amor cortês amores puros que consistem em ver a amada nua e não ir além; ou em deitar juntos, beijar-se, e não penetrar o santuário, a gruta de Vênus. É a mezura, a estética dos sentidos ${ }^{18}$.

Se isso valia para o amor e a corte entre o homem e a mulher, também, a seu modo, era projetado na Virgem, que, assim, ganha contornos ainda mais etéreos e celestiais, particularmente na devoção entre nobres e monges. Amálgama de sensualidade sublimada, platonismo e idealismo, o amor cortês faz da Virgem um símbolo da mais alta pureza, da mais ostentosa riqueza e da celestialidade inatingível. Por exemplo, Richard de Saint Laurent, no século XIII, consagra, em um de seus escritos, seis páginas à beleza espiritual de Maria e quarenta à sua beleza física, enaltecendo cada parte de seu corpo. ${ }^{19} \mathrm{O}$ corporal e o espiritual ganham uma unidade inaudita,

${ }^{17}$ LENZENWEGER, 2006, p. 203.

${ }^{18}$ PALACIOS, Isidro-Juan. Aparições de Maria. Lenda e realidade sobre o mistério mariano. Rio de Janeiro: Record, 1994. p. 91.

${ }_{19}$ DUQUESNE, 2005, p. 119. 
em que o corpo é sublimado e espiritualizado idealmente. Grün e Reitz ${ }^{20}$ veem na representação de Maria como toda bela - Tota pulchra -, ou como lírio do campo, um símbolo da sexualidade, no sentido de integrá-la, por meio de Maria, no contato entre o ser humano e o sagrado.

Duquesne, referindo-se ao amor cortês que, em parte, moldou novas relações devocionais com a Virgem toda bela, descreve que:

na vida real, o senhor domina sua esposa; seu matrimônio foi "arranjado". Mas, no "amor cortês", a mulher é soberana (o termo será aplicado a Maria), e o homem é seu vassalo. A mulher amada é chamada de "Dama", em alusão à esposa do senhor. Ela é sempre colocada num nível mais elevado do que aquele que deseja ser amado por ela. Para merecer a benevolência de sua dama, o cavaleiro deve enfrentar sem hesitar os maiores perigos, cumprir as mais elevadas proezas guerreiras, celebrar sua beleza, servi-la. Ele vive ajoelhado aos seus pés, cercando-a de atenções. Prometeu sua fé, não poderia traí-la ${ }^{21}$.

Maria torna-se, aqui com toda força, $a$ Senhora, não só porque reina junto a seu Filho e Senhor, mas porque agora também é exaltada em sua condição feminina, em seu ser mulher, mas como a mulher perfeita, a nova Eva, a Imaculada ${ }^{22}$. Conforme Jacques Le Goff,

se pensarmos que esse culto a Maria [na Idade Média] é contemporâneo da transformação do matrimônio em sacramento, de uma promoção da criança e da família estrita, conforme demonstram as natividades, é preciso ver na Virgem a grande auxiliadora da condição da mulher ${ }^{23}$.

De fato, na alta Idade Média as mulheres podiam ser caracterizadas como Jezebel ou Dalila ${ }^{24}$, ou seja, relacionadas com a idolatria | heresia ou com a traição. A figura de Maria, no entanto, foi aos poucos se impondo como o modelo ideal de mulher; e ser como Maria era suplantar as figuras negativas ligadas às mulheres, particularmente a figura de Eva. Na urbi et orbe medieval, a mulher é valorizada e dignificada através da figura de Maria em seus vários títulos ou funções. Características como a de mediadora ou intercessora, mãe e advogada (misericórdia), pena (educadora), rainha (dignificadora), parto e leite (família, sustento) atenuam a figura da mulher associada à Eva pecadora. ${ }^{25}$ Bernardo de Claraval, um dos pioneiros no desenvolvimento do culto à Virgem na viragem para a baixa Idade Média, destaca, na esteira incipiente

${ }^{20}$ GRÜN; REITZ, 2009, p. 109.

${ }^{21}$ DUQUESNE, 2005, p. 109.

${ }^{22}$ É justamente a partir do século XIII, com os franciscanos, que a pregação sobre a imaculada conceição de Maria ganha fôlego.

${ }^{23}$ Apud DUQUESNE, 2005, p. 113.

${ }^{24}$ THOMSON, Oliver. História do pecado. Lisboa: Guerra e Paz, 2010. p. 180.

${ }^{25}$ ALVES, Kathia. Virgo Maria, Domina Nostra, Mediatrix Nostra, Advocata Nostra. In: Coletânea, Revista de Filosofia e Teologia da Faculdade de São Bento do Rio de Janeiro, Ano X, Fascículo 20, p. 175-192, julho/dezembro 2011. p. 177. 
do amor cortês, a ternura feminina como uma das características da Virgem. ${ }^{26}$ Maria, portanto, passa a ser figura exemplar para a reversão da imagem feminina, operando a transformação dos paradigmas femininos, de porta do pecado à porta da salvação, e é, ou passa a ser, para as mulheres o exemplo e a companheira para os momentos cruciais da vida ligados às realidades femininas (parto, amamentação e educação, particularmente).

Portanto Maria, para a devoção das mulheres, torna-se um poderoso símbolo de determinada emancipação feminina, pois vendo nela a Mãe de Deus - a mulher que "permite" Deus vir ao mundo, que gera Deus - provocar-se-ia, entre as mulheres, a aceitação de sua própria corporeidade, da dignidade da mesma, não permanecendo elas apenas filhas do pai que, ao casarem-se, passam aos maridos. ${ }^{27}$ Assim,

vê-se logo que Maria concebe uma criança sem a intervenção do homem. Portanto, a mulher recebe sua vitalidade não do homem, mas de Deus. Não está sujeita ao homem como deseja a sociedade patriarcal, mas pode chegar à maturidade por si mesma e tornar-se fecunda [...] a virgem que gera uma criança é, seguramente, a mais alta forma de emancipação que se pode imaginar ${ }^{28}$.

Neste sentido, durante muitos séculos - dominados por exacerbado patriarcalismo e negação de dignidade às mulheres -, Maria terá sido figura de refúgio libertador para as mulheres. ${ }^{29} \mathrm{~A}$ principal cena bíblica referente a Maria, por exemplo - a da anunciação -, revela que Deus (seu anjo) não se dirige nem a José, nem aos homens da família, nem aos representantes dos poderes religiosos instituídos para anunciar a vinda do Messias, como era de se esperar em uma cultura altamente patriarcal, mas a uma pobre mulher adolescente. Que Deus trate de tais assuntos diretamente com uma menina é paradigma de dignidade e autonomia para a autoimagem feminina.

${ }^{26}$ THOMSON, 2010, p. 186.

${ }^{27}$ GRÜN; REITZ, 2009, p. 30.

${ }^{28}$ GRÜN; REITZ, 2009, p. 64.

${ }^{29}$ Essa análise de Grün e Reitz, embora não se refira, historicamente, ao período medieval, é, contudo e guardadas as devidas proporções, aplicável a ele, ainda que de forma ideal, ou seja, potencialmente a figura de Maria passa a poder ressignificar a autoimagem da mulher. 


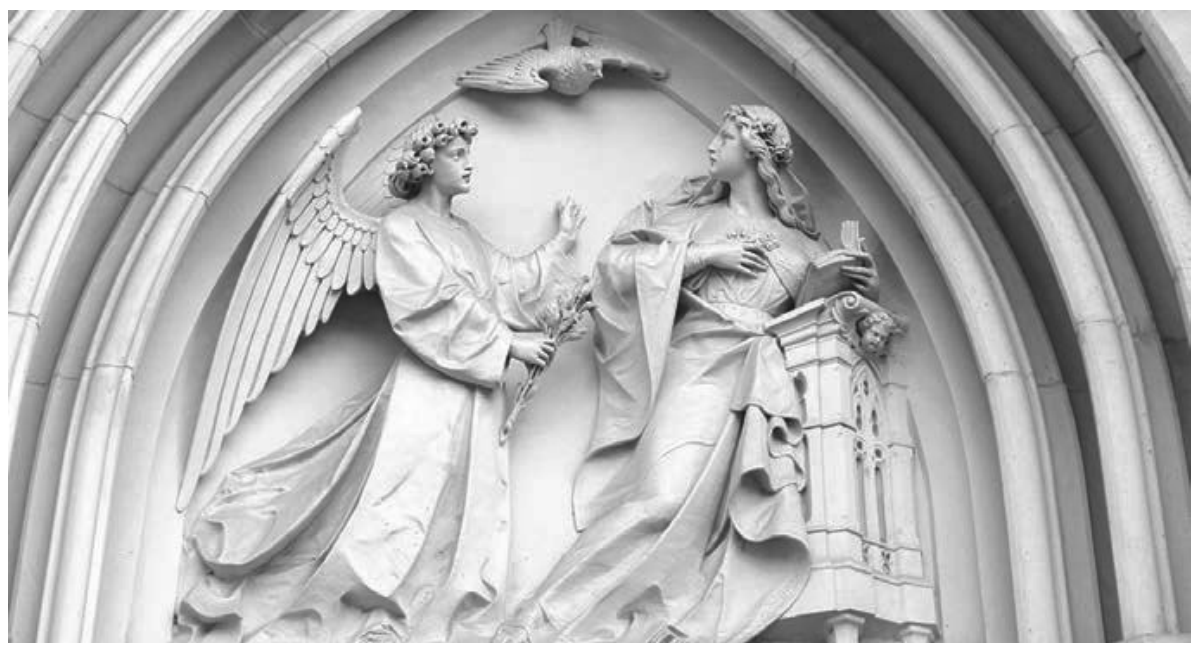

Figura 6. Anunciação, relevo gótico na Catedral de São Wenceslau, Olomouc, República Tcheca ${ }^{30}$

Mas a grande autonomia, neste caso, é a de uma menina - contra toda a lógica biológica e sob o peso social da suspeita e repúdio que sobre si cairiam - decidir aceitar a hierogamia, que, conforme o relato lucano, era proposta à sua livre decisão. Significa isso não menos do que a partida de Abraão, pela fé, ao desconhecido, ou aquilo a que Søren Kierkegaard chama de salto de fé, ou salto no escuro, em meio a toda tragicidade ou angústia que tal atitude envolve. Só quem é, de fato, livre e autônomo o pode realizar.

Tal autonomia, entretanto, é diversa - a partir do ponto de vista estritamente teológico -, de determinadas concepções de autonomia atuais, devedoras da emancipação dos humanos em relação à religião. Trata-se, aqui, de ser livre, mas, fundamentalmente, de ser livre de si mesmo. Portanto, em perspectiva teológica, o conceito liberdade ajuda mais do que o conceito autonomia ${ }^{31}$. Assim pode-se dizer que Maria

${ }^{30}$ Ao contrário de muitas iconografias da Anunciação, que apresentam a Virgem com semblante tranquilo e submisso, aqui o rosto de Maria expressa o drama do momento e seu mysterium tremendum et fascinans (Rudolf Otto).

${ }^{31}$ Auto-nomoi, em grego, significa o eu fazer suas próprias leis, ser sua própria medida. Já liberdade - eleutheria -, cuja etimologia abre a possibilidade de maior número de interpretações, significa a possibilidade de movimento, ou o livrar-se de algo que impede o movimento. É possível compreender, teologicamente, que a autonomia - auto|nomoi, entendida literalmente como o eu que faz seu próprio caminho (portanto não como uma emancipação biológica e psíquica necessária à individualização) - é justamente o fator que impede o movimento (para Deus e para os outros), pois é um aspecto autolimitador do ser, que se volta para si mesmo como medida e como juiz de sua própria medida. Liberdade, ao contrário, seria sair de si, ir ao encontro da lei do (O)outro, da medida diversa, da alteridade, não necessariamente em sentido passivo, mas em sentido dialético e sintético (ou de comunhão). Nas palavras de John Milbank: "No cristianismo, Deus é pensado como pedindo apenas a oferta do nosso livre-arbítrio, numa resposta de amor a ele. Isto já não é, de forma alguma, uma autodestruição ou uma autodivisão, mas antes uma autorrealização, uma 
seria a figura antípoda do "programa antropológico da actualidade [que] gira à volta da 'emancipação' com uma radicalidade que antes não se conhecia, [que] está em

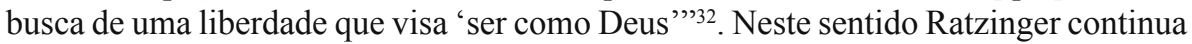
a argumentar que tal atitude é, justamente, o contrário da liberdade, que, por sua vez, pressupõe ao ser humano decisões a partir de critérios exteriores a si mesmo.

Em suma: a autêntica liberdade - e, portanto, autonomia - poderá estar mais relacionada com o assentimento - em obediência - ao extra nos - como no "sim" de Maria ao anjo, mesmo em brumas do que estava a se passar - do que no arbítrio próprio e soberano da vontade egocentrada, a partir apenas de critérios interiores ao self (o self made [pós]-moderno).

Contudo, a ligação da dignidade da mulher à figura modelar de Maria - e, no caso, particularmente à sua castidade -, apresentava (e apresenta) o risco de as mulheres casadas serem vistas como não castas. ${ }^{33}$ Portanto é possível, também, interpretar a maternidade virginal de Maria - em sua relação com o significado dado à vida das mulheres - através de chaves críticas, como evidencia Bruno Forte:

através do modelo de humildade e de silêncio virginal, foi alimentada a passividade feminina; mediante a figura da mulher dissolvida na maternidade divina, foram obscurecidas outras potencialidades da criatividade feminina; com a apresentação de um modelo inatingível, foram postas as premissas para as frustrações mais dolorosas das mulheres. Enfim, quando pareceu que se tratava da exaltação da mulher através da celebração de Maria, na verdade deu-se ensejo ao expediente machista de exaltar uma só mulher para rebaixar todas as outras ${ }^{34}$.

A figura de Maria, neste sentido, apresenta sinal ambíguo para a vida e para a emancipação feminina, pois ao exaltar a figura da mulher, exalta a figura de uma mulher específica que se distancia das demais. Ou seja: a mulher que não fosse como Maria seria como Eva?

Essa crítica a uma imagem e imaginário idealizado - e talvez, na perspectiva de alguns, ideológico - sobre a Virgem Maria, também é estendida à iconografia e imaginária que envolve Jesus e os santos. Assim, a iconografia, embora possa retratar o "caráter humano do sagrado", sua proximidade a nós e ao nosso mundo, pode, também, realçar um modelo de perfeição moral e estética inalcançável, acentuando, por contraste, a pecaminosidade, fealdade e impotência humanas em comparação à "perfeição" das figuras sagradas retratadas. ${ }^{35}$

oferta que é simultaneamente a nossa recepção da plenitude do Ser. É a recepção de Deus: 'Deificação'. É o Sacrum Facere" (Apud GOMES, Pedro Valinho. Sacrum Facere: a cidade dos dons sacrificiais. In: SUMARES, Manuel; CATALÃO, Helena; GOMES, Pedro Valinho (Orgs.). Religiosidade: o seu carácter irreprimível. Perspectivas contemporâneas. Braga: UCP, 2010. p. 89-98. p. 98).

32 RATZINGER, Joseph; BALTHASAR, Hans Urs von. Maria, primeira Igreja. Coimbra: Gráfica de Coimbra, 2004. p. 27.

33 THOMSON, 2010, p. 223.

${ }^{34}$ FORTE, Bruno. Maria, a mulher ícone do mistério. São Paulo: Paulus, 1991. p. 13.

${ }^{35}$ WOODHEAD, Linda. O cristianismo. Vila Nova de Famalicão: Quasi, 2006. p. 36. 
Por exemplo, vemos isso na imagem moderna retratada abaixo, da sagrada família, a apresentar uma família em grau de harmonia singular, olhares compassivos e compreensivos, atitudes comedidas, formas angélicas, estética estilizada | idealizada. Enfim, um modo de se apresentar a realidade familiar muito distante de qualquer família concreta nossa e, certamente, do que é o ser humano à vera, mesmo o realmente mais santo.

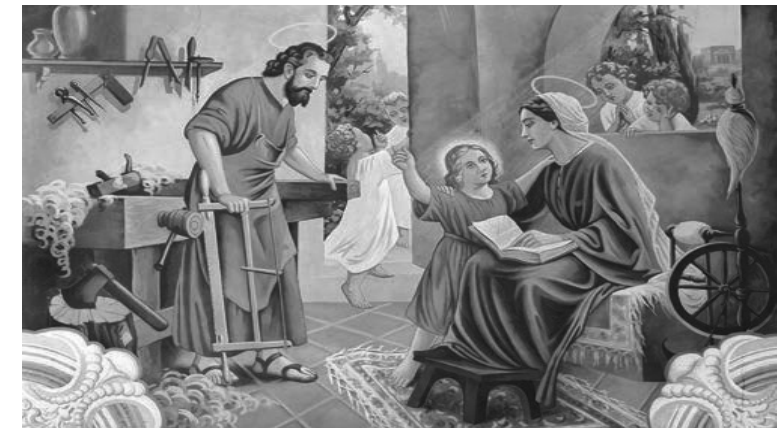

Figura 7. Estampa popular

\section{Da figura ideal-platônica ao chão do povo}

Se, por um lado, Maria ganha ares etéreos e sublimes, em movimento descendente, ela chega ao povo e à sua realidade de forma cada vez mais íntima, enraizada no cotidiano das pessoas. Já a consagração das catedrais à Nossa Senhora, nos séculos XII e XIII, mostra a revalorização do mistério da encarnação ${ }^{36}$, ou seja, passa-se a valorizar Deus que nasce tornando-se humano e partilhando o fado comum da humanidade. É justamente a partir dessa época que as imagens de Jesus sofredor na cruz passam a ter maior destaque na iconografia dos templos - ao contrário do dantes Jesus reinante, de olhos abertos, na cruz -, e que Francisco de Assis cria a representação do presépio vivo, reforçando a humanidade do Deus-menino. Também é por volta dessa época que a reforma cisterciense introduz estética arquitetônica e liturgia monástica mais despojada, em contraponto ao fausto artístico e litúrgico de Cluny.

Enfim, os séculos XII a XIII marcam uma importante viragem na base da igreja, aproximando mais o Deus Pantocrator do Deus compassivo. Contudo, mesmo com a paulatina mudança das sensibilidades religiosas, Jesus (Deus) continua ainda muito longe, inacessível ao povo. Santos, mártires e Maria continuam a ser as referências básicas dos humildes. Mas, agora, Maria se torna mais próxima, pois é interpretada como aquela que, colocando Deus no mundo, tem o privilégio de, junto a ele, suavizar sua ira e advogar suas graças. Neste sentido Maria passa a ser representada como a que socorre o povo em suas necessidades, que vive as triviais intimidades do dia a dia popular.

${ }^{36}$ DUQUESNE, 2005, p. 110. 
Pode-se iniciar tal percurso de visão mariana percebendo como a Virgem passa a ser envolvida no cotidiano popular, em seus milagres, maravilhas e mundo do fantástico. A porta para tanto, claro, são as legendas ${ }^{37}$, que, muito além de aspectos fantasiosos ou pueris que pudessem ter, tiveram e têm a força de criar devoções, santuários, peregrinações, votos, consagrações. Grosso modo pode-se seguir o seguinte roteiro - com matizes e variantes - da nova piedade popular mariana:

las leyendas pueden sintetizarse del modo siguiente. Un hombre recibe señales extraordinarias o encuentra a una imagen - nunca se dice de qué materia ni naturaleza -, no da crédito a sus sentidos, duda y es confortado por ella que le da pruebas de su poder curándole alguna minusvalía; lo comunica a las autoridades eclesiásticas y civiles locales. [...] Es significativo el hecho de que en todas las leyendas, una vez que el vidente se ha recuperado de su asombro y la imagen ha resuelto favorablemente la credibilidad del suceso mediante un milagro, del que él mismo es beneficiario, marcha a la ciudad o villa y se presenta a las autoridades eclesiásticas, frecuentemente también civiles, para darles conocimiento del suceso portentoso. Esta actitud, que recogen sistemáticamente los textos, la interpretamos como una prueba de la identificación del icono con la población y el territorio donde se supone tuvo lugar la aparición o hallazgo. Más significativo es el hecho de que las ermitas y santuarios estén siempre en el campo, a cierta distancia de los núcleos urbanos. [...] con una tenacidad impropia de seres humanos, decide el lugar donde quiere residir, y dónde desea se le levante una ermida, que no es sino el lugar de aparición, es decir, lejos del control de las autoridades que implica el núcleo urbano $^{38}$.

O texto anteriormente citado mostra o roteiro - recorrente desde a baixa Idade Média - da criação de determinada piedade mariana autônoma, isto é, independente do âmbito eclesiástico, de seu ambiente oficial e de sua autoridade. Primeiramente, destaca-se que a iniciativa do fomento de determinada devoção é da própria Virgem, que surge de formas inusitadas a leigos e fora do ambiente eclesiástico. É menos comum encontrar relatos de aparições a eclesiásticos ou no ambiente dos templos. Os leigos são, com Maria, os protagonistas, e a natureza - ela que servia aos antigos cultos autóctones das terras cristianizadas na Europa - é o local privilegiado das mariofanias. Em tais locais naturais é que surgem as fontes - outrora sagradas - e que se realizam os milagres e os eventos da ordem do fantástico. Mais: geralmente, a Virgem é explícita em desejar que sua ermida seja construída longe dos centros de poder, como a afirmar outro modelo de poder, outro centro gravitacional para a fé. Contudo, na altura, não se vive sem a igreja, sem sua bênção. Portanto o movimento seguinte é o de ir às autoridades - eclesiásticas e civis - para a apresentação do portento. Maria

37 A palavra legenda é, geralmente, concebida como sinônimo de lenda. Contudo, o conceito original, a partir da etimologia, é outro: legenda era o relato da vida de um santo destinado à leitura pública no âmbito dos mosteiros e igrejas. A mentalidade e os estilos literários e históricos modernos é que, não podendo admitir como reais muitos dos acontecimentos expostos em tais textos, fizeram evoluir legenda em lenda.

38 BECERRA, Salvador Rodríguez. Santuarios y apariciones marianas en Andalucía (España). In: Revista Santuários, Universidade de Lisboa, v. 1, n. 2, p. 223-226, 2014. p. 225. 
e os leigos invertem a ordem hierárquica, isto é, o leigo leva a mensagem aos pregadores e guardiães da doutrina.

Como já referido, esse tipo de piedade mariana tem início no medievo, mas é recorrente e perdura até os dias atuais. Como exemplo é possível citar que,

em 1530, em Thiene, Itália, houve grande devastação devido a uma praga de gafanhotos. Na altura, três crianças tiveram uma visão de Maria, que estaria sobre um olmo, planta da região. Maria teria dito que a praga se devia aos pecados do povo, mas que, mediante conversões e a construção, ali, de um seu santuário, intercederia pelo povo junto a Jesus ${ }^{39}$.

Nessa história surgem elementos recorrentes nas visões ou comunicações marianas, quais sejam: por diversas vezes os receptores privilegiados das mensagens da Virgem são crianças (ou pessoas pobres); Maria aparece relacionada a algum elemento da natureza (plantas e árvores, fontes, tempestades, sol etc.); a Virgem surge em momentos de crise, na altura de pestes, fomes, guerras etc.; traz mensagens de conversão e de construção de ermidas ou santuários. ${ }^{40}$

Embora as manifestações da Virgem estejam quase sempre relacionadas a leigos, também no âmbito da igreja - nos templos e entre clérigos - a Virgem dá o ar de sua graça, apesar de, nesses casos, geralmente suas manifestações ocorrerem para o baixo clero, que, por sua vez, vinha dos extratos populares e preservava, até certo ponto, a cultura popular da qual era tributário. Como exemplo, Palacios ${ }^{41}$ nos relata uma deliciosa história medieval. Recolhe ele a legenda, dos registros feitos por Vincent de Beauvais, que no século XIV um monge pintava o pórtico de uma abadia. Após pintar a Virgem e o menino, pintou, acima deles, a cena do juízo final, ilustrando, na cena, um demônio de feiura acentuada. Pois bem, não gostando de sua imagem pintada, o próprio demônio retratado veio ao monge e empurrou-o do andaime. Mas, no momento em que o religioso caía, o braço pintado da Virgem saiu do afresco e o segurou. Segundo Vicent de Beauvais, todos os que o assistiam pintar foram testemunhas do milagre.

Como essas, há muitíssimas histórias medievais saborosas em que a Virgem Maria - retratada em pinturas, esculturas, ex-votos - ganha vida e interage com o ambiente à sua volta. Para os medievais, Maria era um ente sobremodo vivo no que diz respeito à sua participação no dia a dia das pessoas, inclusive nos pequenos, banais e singulares acontecimentos. $\mathrm{O}$ mundo encantado participava naturalmente do mundo social e natural, e vice-versa.

Em Huelva, Espanha, cultua-se Nossa Senhora da Cinta. Contam-nos os anais da história que, em 1178, a Virgem surgiu na Catedral de Tortosa, entregando a um cônego um cingidouro de seda feito por suas mãos. Desde esse acontecimento, ao cônego - e depois àquela catedral - vinham as "encintas” (grávidas) para pedir bom

39 ZANON, Darlei. Nossa Senhora de todos os nomes. São Paulo: Paulus, 2007. p. 197.

${ }^{40}$ Esse mesmo modelo também será recorrente, grosso modo, nas grandes aparições marianas dos séculos XIX e XX, mostrando, assim, a continuidade de certo habitus.

${ }^{41}$ PALACIOS, 1994, p. 49s. 
parto. Em 1363, uma constituição eclesiástica definiu que fossem cortados dois pequenos pedaços da cinta milagrosa para que os mesmos pudessem ser levados às casas das parturientes que, no leito do parto, não pudessem se deslocar ao templo. ${ }^{42}$

Maria acode os seus através de presentes, conselhos e intervenções fantásticas. É presença viva em imagens, objetos, pinturas, fenômenos naturais. Contudo, embora Maria aparecesse a crianças, camponeses e, eventualmente, membros do clero, a relação de maior intimidade da Virgem era para com as mulheres, particularmente no que concerne ao parto, à criação das crianças (amamentação e educação) e à saúde.

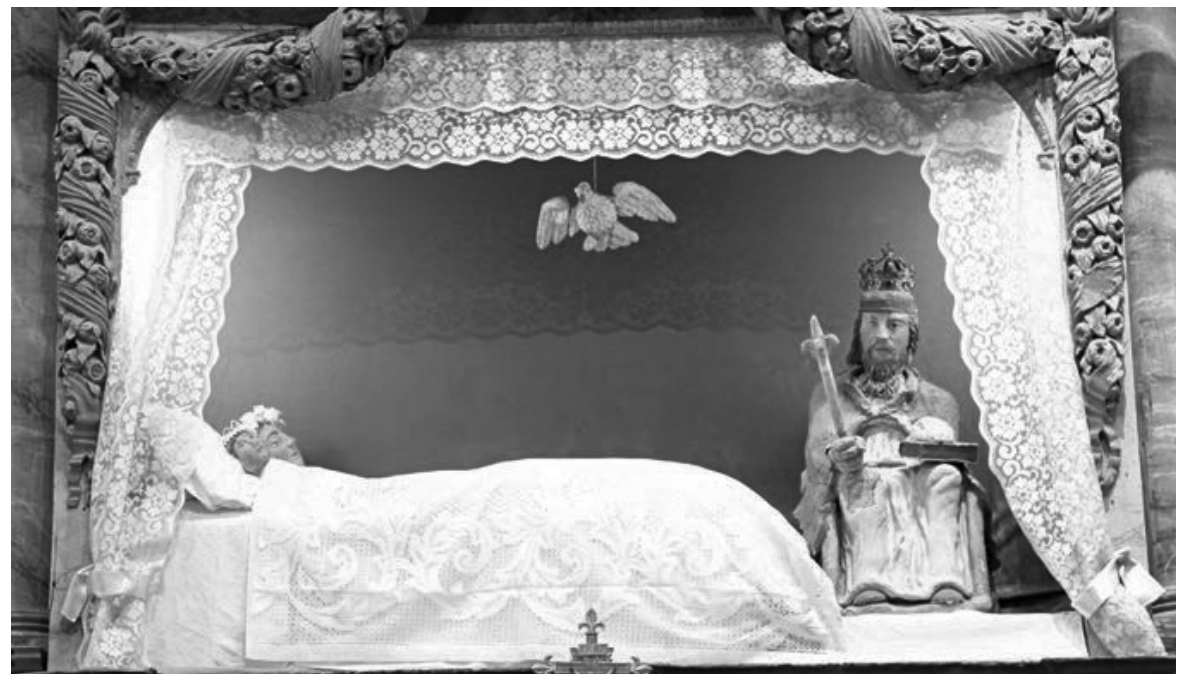

Figura 8. Virgem parturiente (Capela de Yaudet, Bretanha, França)

A Virgem parturiente - acima retratada - é invocada, até os dias atuais, por mulheres que desejam engravidar. Para tanto, as mulheres recitam o rosário, mensalmente, aos seus pés. ${ }^{43}$ Chamo a atenção para o tipo de representação em sua liberdade criativa, isto é, o artista representa a Virgem deitada na cama, após as dores do parto, convalescente, já com o recém-nascido Jesus ao seu lado, e com Josée ${ }^{44}$ a velar por ambos (e com a pomba, a representar o Espírito Santo, que revela a origem sagrada da gestação). Se Maria, grávida ou parturiente, foi - e é - referência importante na devoção popular (particularmente para as mulheres), mais forte, entrementes, foi a devoção à Nossa Senhora do Leite, à Virgem que amamenta, sendo a amamentação, sem dúvida, um forte símbolo de vida, alimentação, e abrindo o leque de significados variados.

${ }^{42}$ PALACIOS, 1994, p. 117.

${ }^{43}$ BOYER, Marie-France. Culto e imagem da Virgem. São Paulo: Cosac \& Naify, 2000. p. 29.

${ }^{44}$ A imagem de José apresenta certo hibridismo com a tradicional figura de Deus Pai. A coroa em sua cabeça realça sua ascendência davídica. 


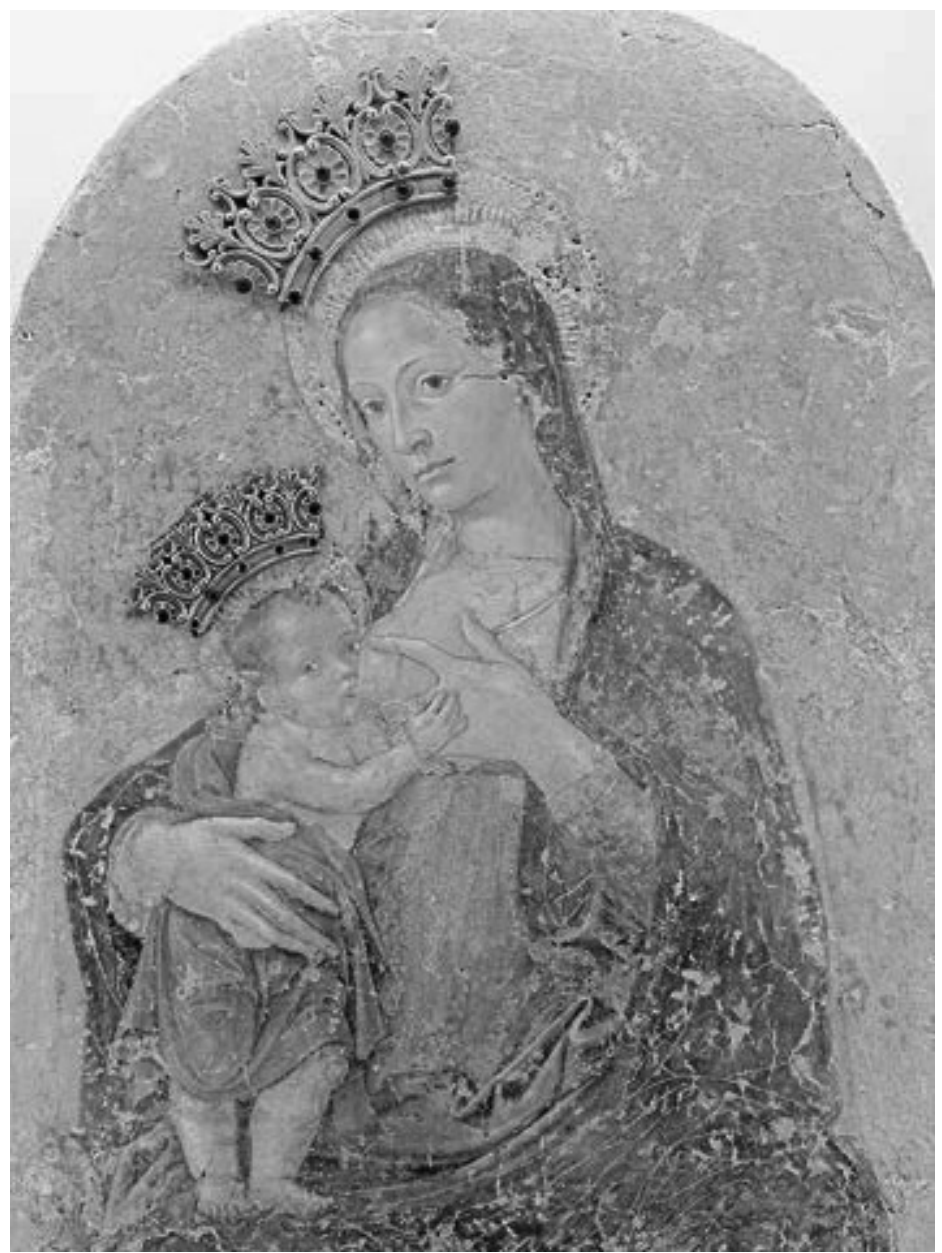

Figura 9. Nossa Senhora do Leite (Antoniazzo Romano, igreja da Anunciação, Roma, Itália, século XIII)

A primeira característica que salta aos olhos, inclusive e talvez ainda mais ao olhar pudico, é que Maria aparece com o seio à mostra. A partir da cultura cristã da época (e de constância residual até hoje), em que o corpo estava sob suspeita - particularmente o das mulheres - e que a nudez (mesmo parcial) era considerada, sob o ponto de vista religioso, temerária, é assaz surpreendente que desde cerca de mil anos atrás até os dias atuais - e de forma mais abundante no medievo -, Maria fosse, de diversas formas, retratada com o seio à mostra. Claro está que, também no cristianismo, o ato de amamentar é considerado positivamente e que a imagem de uma mãe a amamentar seu filho é deveras significativa quanto ao amor materno e a tudo que ele pode representar em tal imagem: cuidado, alimentação, doação, carinho. Contudo, a julgar pelas demais imagens e representações de Maria - e dos santos, santas e Jesus, 
em geral -, podemos notar que dificilmente encontram-se imagens a destacar, ainda que por pios motivos, partes do corpo - particularmente da mulher - que eram consideradas íntimas. ${ }^{45}$

Aqui, evidentemente, não faço tais observações a partir da literatura bíblica ou da cultura antiga, que podiam apresentar cenário mais livre em relação à nude $z^{46}$, mas falo a partir do cristianismo já consolidado na Idade Média, de acento teológico marcado pela suspeita em relação ao corpo e ao sexo. Neste sentido, as imagens de Nossa Senhora do Leite são uma prova enfática de que Maria, a maternidade e o amor de ligação entre mãe e filho são tão sumamente profundos no imaginário e na realidade humana que, mesmo sob o peso das interdições e suspeitas relativas ao corpo, conseguiram romper fronteiras na arte religiosa e devocional, e celebrar Maria a partir da amamentação dada a Jesus, e, claro, como inevitável, retratando parte íntima de seu corpo essencial a esse ato.

Também percebo que se deve ver, nessa licença artístico-devocional, uma vitória das mulheres (ou de Maria em favor delas). A vitória de demonstrar a um mundo machista e patriarcal - e, claro, a um clero e igreja de antanho ainda mais patriarcal, e de suspeitas e condenações à mulher e ao seu perigoso e tentador corpo desnudo - que o seio, ao menos ao amamentar, é algo sagrado, fonte feminina da qual dependeu o próprio menino-Deus, figura de beleza a expressar amor e doação. Maria com seu seio aparente a amamentar como que redime o corpo feminino da ideia de raiz do pecado, do corpo feminino como tentação, matizando seus aspectos considerados negativos e dotando-o de pureza e sacralidade. Sim, dirão, é o seio da mãe de Deus, isto é, não é o corpo das "filhas de Eva", mas da nova Eva redimida. Aqui surge a interpretação de que Maria, sendo quem é, mais oprime as mulheres - impingindo a elas um ideal inalcançável - do que concede com suas imagens, a elas, possibilidades de autonomia social.

Porém estamos, aqui, a lidar com elementos simbólicos (imagens), e o símbolo, como já esboçado, abre horizontes, ao contrário dos conceitos que tendem a fixar compreensões unívocas. O símbolo leva à pluralidade semântica, hermenêutica e vital, podendo abrir várias portas de intuições e de entendimentos. Portanto a imagem-símbolo é sua própria pregação, e seu sentido é sempre contextual e pessoal. Maria, em uma mesma imagem-mensagem, pode tanto justificar e legitimar como subverter

45 Inclusive, conforme Emília Nadal (NADAL, Emília. Maria na iconografia cristã. In: Maria nos caminhos da Igreja. Semanas de Estudos Teológicos da Universidade Católica Portuguesa. Lisboa: Verbo, 1991. p. 117-140. p. 131), "muitas Senhoras do Ó foram retiradas, após o Concílio de Trento, destruídas ou enterradas em cemitérios e adros de igrejas, por serem consideradas impróprias para o culto. Pelas mesmas razões foram vestidas outras imagens". Já a imagem de Jesus crucificado o traz, quase sempre, seminu (os condenados à cruz eram, entretanto, crucificados totalmente despidos). Porém, tal imagem já se tornou tão comum e naturalmente incorporada à cultura ocidental que, na maior parte das vezes, não é percebida - ao menos em um sentido erótico, ou que o valha - essa característica da imagem. Claro está que se trata de um homem seminu torturado e morto, o que não convém, certamente, a um olhar que privilegie o corpo em sua dimensão erótica. Mas, de qualquer forma, é imagem a qual já estamos acostumados culturalmente, inclusive em sua avaliação da dor e sofrimento nela contida.

${ }^{46}$ A Bíblia apresenta muitas histórias e imagens de teor sexual e erótico (apenas como um exemplo, o livro do Cântico dos Cânticos), e, igualmente, em culturas antigas que influenciaram o cristianismo, como a greco-romana, havia abundância de imagens de deuses e deusas seminus. 
e oferecer novos paradigmas para determinada compreensão antropológica, teológica e sociológica, dentre outras. Na religião popular, o símbolo se constitui em algo que

nunca é adequado, que nunca é objetivo, visto que nunca atinge um objetivo, que pretende sempre ser essencial, uma vez que se basta a si próprio e é escandalosamente o portador da mensagem imanente duma transcendência, que nunca é explícito, mas sempre ambíguo e mesmo redundante ${ }^{47}$.

A arte é mediação ativa para o conhecimento e para a experiência de sentidos, ou para a subversão deles. Portanto a arte é intrinsecamente ambígua como linguagem simbólica. ${ }^{48}$

Na figura 10 é possível ver a figura de Maria em sua intimidade, deitada no leito, e de Jesus menino a buscar, no interior da roupa de Maria, o seio para sua alimentação. É notável que Maria tenha sido, desde muito, figurada com tanta intimidade, uma intimidade acentuadamente feminina e do âmbito do lar e do carinho interdependente entre mãe e filho.

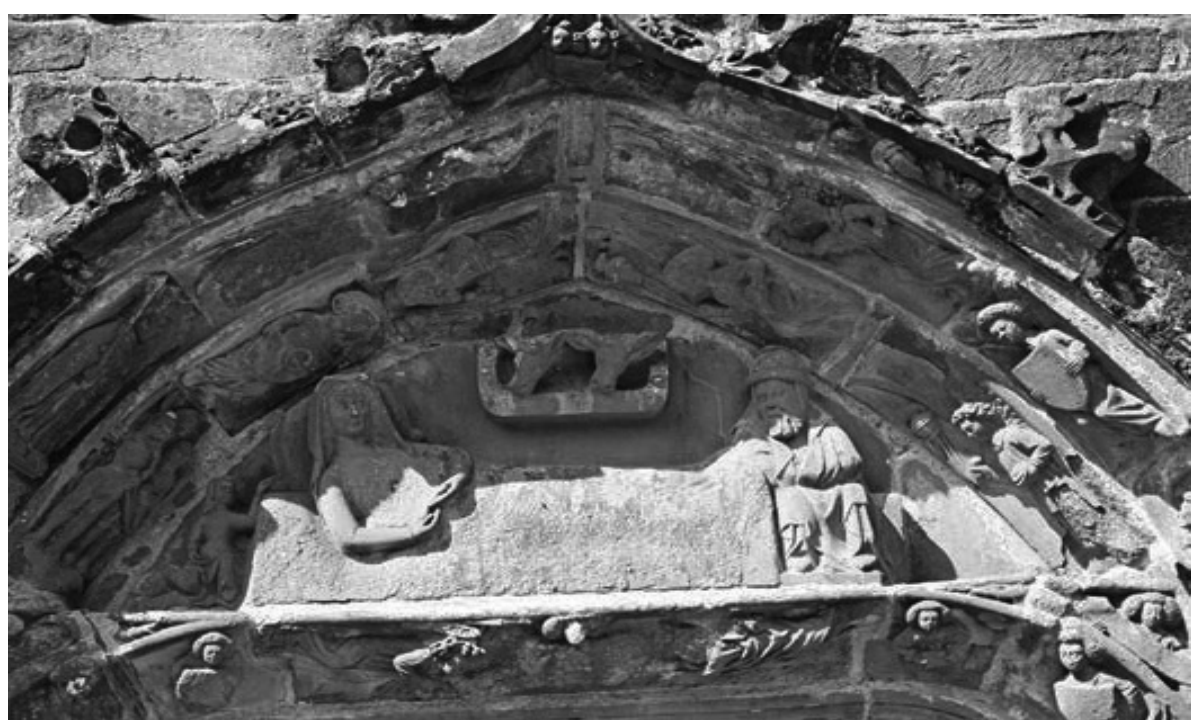

Figura 10. Maria parturiente. Tímpano da Igreja de São Salomão, França, 1450

É ainda de se destacar que Virgens do Leite foram padroeiras das amas de leite, quando as mães confiavam seus filhos a essas. ${ }^{49} \mathrm{Ou}$ seja, Maria, em seus "exercícios de intimidades maternas", digamos assim, circula no imaginário feminino - e eclesial-

${ }^{47}$ DURAND, Gilbert. A imaginação simbólica. Lisboa: Arcádia, 1979. p. 20.

${ }^{48}$ NADAL, Emília. Arte e mundividências. A comunidade, o homem e o religioso. In: Theologica, Universidade Católica Portuguesa - Faculdade de Teologia, v. XXX, Fasc. 1, p. 43-56, 1995. p. 46.

49 BOYER, 2000, p. 30. 
-teológico, pois são imagens e devoções existentes nas igrejas - de forma a conferir ao papel de mãe a atribuição central de dignidade da mulher. E de fato, no judeu-cristianismo - ou ao menos nas tradições teológicas mais antigas desses dois monoteísmos - a dignidade da mulher está em ser mãe, em criar os filhos, no cuidado do lar. ${ }^{50}$

Segundo Espírito Santo 51 , "não há [ao menos em Portugal] imagens nem cultos de Maria-filha, Maria-esposa, Maria trabalhadora doméstica, Maria-boa-vizinha. Todas são Maria-mãe, Maria que vai ser mãe ou Maria junto de sua mãe". Mas, conforme o etnossociólogo, não é privilégio da cultura judaico-cristã esse papel imprescindível da mulher, o de ser mãe. Avança o estudioso em constatar que, de forma geral, a figura mesmo da mulher cumpre um papel ímpar, pois ${ }^{52}$ :

Só a imagem da mãe é mobilizadora. Para se oporem simultaneamente ao Rei e à Igreja, os sans-culottes criaram a figura de Marianne [...]. Os camponeses portugueses de 1846 combateram o Estado em nome de Maria da Fonte [...] O símbolo mais mobilizador dos comunistas portugueses é uma mulher camponesa, Catarina Eufémia [...]. A nação é a alma do povo. [...] É sempre a imagem de uma mãe que é invocada: a Pátria, a Nação, a Democracia, a Liberdade, a República, a Revolução, a Constituição, a Justiça - todas elas figuras femininas e sempre representadas por mulheres, de seios transbordantes, abraçando os filhos ou empunhando uma espada para defender as crianças que se the agarram às saias ${ }^{53}$.

${ }^{50}$ Ser mulher estéril, no Antigo Testamento da Bíblia, era muitas vezes considerado como uma desgraçada maldição. Gerar muitos filhos, por sua vez, era sinal de bênção (cf. Gn 20.17-18; 25.19-27; 30.1).

${ }^{51}$ ESPÍRITO SANTO, Moisés. Origens orientais da religião popular portuguesa. Lisboa: Assírio \& Alvim, 1988. p. 27.

52 Não pretendo cair na tentação etnocêntrica e essencialista de dizer que esse papel da mulher e da mãe se dá em todos os povos e culturas, como parece sugerir o autor. Seguindo Espírito Santo, admito o papel ímpar da mulher - e, mais, da mulher que é mãe -, mas, também, me distanciando um pouco do entusiasmo manifestado pelo erudito investigador português, anoto um "talvez". É sabido que na particularidade histórica e íntima de cada pessoa e família, nem sempre as relações com os genitores são tranquilas e, por vezes - por vários motivos que de forma alguma caberia aqui analisar -, tais relações são mesmo conflituosas e antipáticas. E a história registra, igualmente, atrocidades - do ponto de vista da cultura cristã - perpetradas por filhos aos pais e por pais aos seus filhos. Mesmo Jesus relativizou - a partir do ponto de vista escatológico - a figura da mãe (Mc 3.34-35) e deixou claro que, por causa dessa mesma dimensão escatológica, cisões se dariam no forte mundo familiar e clânico, que marcava as culturas antigas, como a judaica (Lc 12.49-53). Também é preciso referir, a partir do lastro das culturas populares, o dito de que há "mães desalmadas" (e também filhos). Sigmund Freud, por sua vez, ofereceu novas chaves de entendimento para certas relações familiares patológicas. Contudo, fica registrado o benefício da dúvida para os que, romanticamente ou não, atribuem uma essência final (boa e imprescindível) para a figura da mãe. Talvez Salomão fosse um desses (1Rs 3.16-28). De todo modo, pode-se afirmar, talvez com alguma certeza, que a devoção a Maria - a refletir alguma continuidade com o culto das deusas mães antigas apontaria para uma dependência infantil em relação à mãe, uma "saudade da mãe", como afirma Jung (apud GRÜN; REITZ, 2009, p. 24).

${ }_{53}$ ESPÍRITO SANTO, Moisés. A religião popular portuguesa. Lisboa: Assírio \& Alvim, 1990. p. 213. 


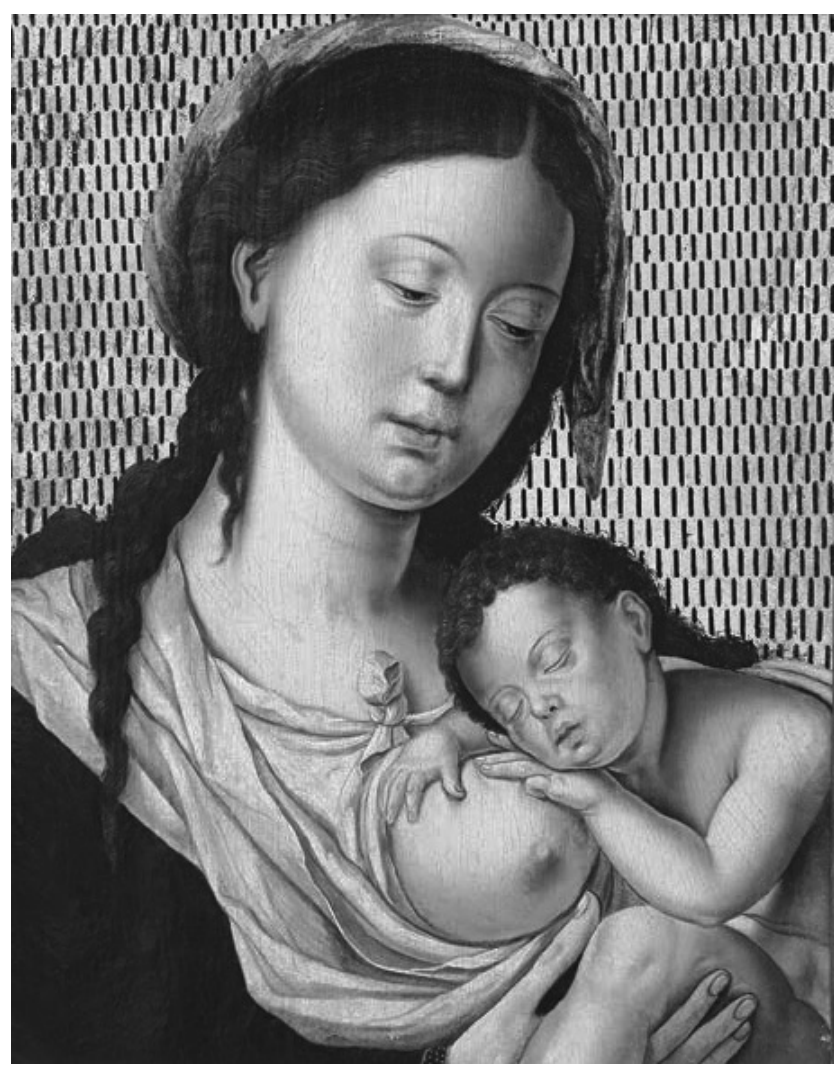

Figura 11. Madonna com a criança, Academia Croata de Ciências, Zagreb, Croácia

Ainda a sublinhar a sensibilidade antiga para com a Virgem do Leite, a pintura da Madonna com a criança mostra um Jesus sereno a dormir de barriga cheia, após sugar os peitos de sua mãe, que, por sua vez, olha para o menino com olhar complacente, satisfeito e meigo. São imagens de uma intimidade que as mulheres, por certo, logo relacionam à sua vida, ao seu cotidiano, ao ato poderoso de fazer adormecer ou serenar as dores e angústias de uma criança. Isso não seria um doce poder? Ou, em outras palavras: "Maria está não ao lado de Deus, mas diante dele. Não para escondê-lo, e sim para envolvê-lo numa luz humana, numa luz feminina e materna" ${ }^{54}$.

\section{Conclusão}

No curto espaço que um artigo impõe, e com os devidos recortes que exige, podemos concluir que, quando Maria ainda era, no início da Idade Média, fator de dis-

${ }^{54}$ GRÜN; REITZ, 2009, p. 13. 
putas entre teólogos - relativamente aos primeiros dogmas da igreja ligados, direta ou indiretamente, a ela -, e, também, quando era, em tais disputas, elemento de legitimação do poder imperial - civil e eclesiástico -, Maria ganha ares de imperatriz, e ainda está um tanto longe da devoção mais popular como, mais tarde, ocorrerá. ${ }^{55}$ Contudo, serenados os ânimos das disputas dogmáticas e imperiais, Maria começa a ser mais apropriada pelo povo, não antes, talvez, de passar pelos mosteiros, particularmente aqueles cistercienses, que dão novas notas aos significados de Maria e às relações dos cristãos para com ela.

Maria, na transição para a baixa Idade Média, vai, gradativamente, tornando-se a mulher que, em seus aspectos humanos, identifica-se com as mulheres, com a casa, com as aflições femininas, mas, de forma geral, com as aflições e esperanças humanas, sendo a mediadora próxima de um Deus distante. E mediadora feminina e materna, a atenuar o acentuado caráter masculinizado que Deus, e a igreja, imprimiam ao cristianismo. Neste sentido, pode-se dizer que, durante a Idade Média, é gestada a figura da mãe de Deus e de importantes características, significados e imaginárias sobre a Virgem Maria.

\section{Referências}

ALVES, Kathia. Virgo Maria, Domina Nostra, Mediatrix Nostra, Advocata Nostra. In: Coletânea, Revista de Filosofia e Teologia da Faculdade de São Bento do Rio de Janeiro, Ano X, Fascículo 20, p. 175-192, julho/dezembro 2011.

AMATO, Pietro. Arte|Iconologia. In: DE FIORES, Stefano; MEO, Salvatore (Orgs.). Dicionário de Mariologia. São Paulo: Paulus, 1995. p. 151-163.

BARNAY, Sylvie. Maria. In: VAUCHEZ, André. Cristianismo. Dicionário dos tempos, dos lugares e das figuras. Rio de Janeiro: Forense Universitária, 2013. p. 263-264.

BECERRA, Salvador Rodríguez. Santuarios y apariciones marianas en Andalucía (España). In: Revista Santuários, Universidade de Lisboa, v. 1, n. 2, p. 223-226, 2014.

BEIRANTE, Maria Ângela. Territórios do Sagrado. Crenças e comportamentos na Idade Média em Portugal. Lisboa: Colibri, 2011.

BOYER, Marie-France. Culto e imagem da Virgem. São Paulo: Cosac \& Naify, 2000.

DUQUESNE, Jacques. Maria. Rio de Janeiro: Bertrand Brasil, 2005.

DURAND, Gilbert. A imaginação simbólica. Lisboa: Arcádia, 1979.

ESPÍRITO SANTO, Moisés. A religião popular portuguesa. Lisboa: Assírio \& Alvim, 1990. . Origens orientais da religião popular portuguesa. Lisboa: Assírio \& Alvim, 1988.

FORTE, Bruno. Maria, a mulher ícone do mistério. São Paulo: Paulus, 1991.

GOMES, Pedro Valinho. Sacrum Facere: a cidade dos dons sacrificiais. In: SUMARES, Manuel; CATALÃO, Helena; GOMES, Pedro Valinho (Orgs.). Religiosidade: o seu carácter irreprimível. Perspectivas contemporâneas. Braga: UCP, 2010. p. 89-98.

GRÜN, Anselm; REITZ, Petra. Festas de Maria: um diálogo evangélico-católico. Aparecida: Santuário, 2009.

LENZENWEGER, Josef. História da Igreja Católica. São Paulo: Loyola, 2006.

55 Embora também, nessa época, possa ter sido compreendida como rainha dos pobres e das populações mais simples. 
NADAL, Emília. Arte e mundividências. A comunidade, o homem e o religioso. In: Theologica, Universidade Católica Portuguesa - Faculdade de Teologia, v. XXX, Fasc. 1, p. 43-56, 1995. . Maria na iconografia cristã. In: Maria nos caminhos da Igreja. Semanas de Estudos Teológicos da Universidade Católica Portuguesa. Lisboa: Verbo, 1991. p. 117-140.

PALACIOS, Isidro-Juan. Aparições de Maria. Lenda e realidade sobre o mistério mariano. Rio de Janeiro: Record, 1994.

RATZINGER, Joseph; BALTHASAR, Hans Urs von. Maria, primeira Igreja. Coimbra: Gráfica de Coimbra, 2004.

THOMSON, Oliver. História do pecado. Lisboa: Guerra e Paz, 2010.

WOODHEAD, Linda. O cristianismo. Vila Nova de Famalicão: Quasi, 2006.

ZANON, Darlei. Nossa Senhora de todos os nomes. São Paulo: Paulus, 2007.

\section{Referências das imagens}

FIGURA 1. Domínio público. Disponível em: <commons.wikimedia.org>.

FIGURA 2. Domínio público. Disponível em: <commons.wikimedia.org>.

FIGURA 3. Arquivo do autor.

FIGURA 4. Kheat/Shutterstock.com.

FIGURA 5. Michal812/Shutterstock.com.

FIGURA 6. Vladimir Wrangel/Shutterstock.com.

FIGURA 7. Zvonimir Atletic/shutterstock.com.

FIGURA 8. Imagem gentilmente cedida pelo Sr. Jean-Yves Cordier, e disponível em lavieb-aile.com.

FIGURA 9. Renata Sedmakova/Shutterstock.com.

FIGURA 10. Imagem gentilmente cedida pelo Sr. Jean-Yves Cordier, e disponível em lavieb-aile.com.

FIGURA 11. Zvonimir Atletic/Shutterstock.com. 